\title{
TERRA E DESAFORO: VIOLÊNCIA NO CAMPO, BRIGAS E ÉTICAS DE LUTA NOS FAXINAIS DO PARANÁ
}

Dibe Ayoub ${ }^{1}$

\begin{abstract}
${ }^{1}$ Programa de Pós-Graduação em Antropologia Social, Museu Nacional, Universidade Federal do Rio de Janeiro, RJ, Brasil
\end{abstract}

Pinhão, município da região Centro-sul do Paraná, é marcado por um longo conflito envolvendo comunidades tradicionais e uma empresa madeireira. Como outros lugares e conflitos, este também envolve um processo de expropriação e domínio de terras feito com atentados à vida. Porém, os moradores daquelas comunidades raramente lançam mão do termo violência para falar sobre as agressões, as ameaças, os assassinatos, os despejos e as arbitrariedades que vivem nessas disputas. Ao invés dele, acionam categorias particulares, como as brigas e os desaforos, indicativas de um léxico e um estilo de narrar que são também formas de viver e reconhecer violações. ${ }^{1}$ Longe de estruturarem uma tipologia da violência ou um domínio normativo, estes termos dizem respeito aos modos com que os sujeitos problematizam as experiências de abuso, morte e destruição percorridas em sua luta, fazendo delas matéria de cuidado, agência, reivindicação e contestação da terra.

Realizo trabalho de campo em diferentes comunidades do interior de Pinhão, sobretudo com famílias que participam ou participaram dos movimentos sociais atuantes no município. Neste texto, particularmente, dialogo com interlocutores que se autodenominam posseiros. Elaborada na luta com a madeireira e através do Movimento de Posseiros, instituído em Pinhão em 1992, essa identidade expressa seu vínculo com as áreas onde vivem, consideradas posses, pois eles não portam os títulos de propriedade da terra. Muitos posseiros vivem em terras de herança ou posses antigas, onde suas famílias se assentaram entre meados do século XIX e início do XX. Essas áreas se caracterizavam pelo "sistema faxinal" (Chang 1988; Almeida 
2006; Porto 2013), em que os planaltos com mata de araucárias dão lugar a faxinais, terras de uso comum para a criação de animais, e as serras e as beiras de rio consistem em ambientes de produção de roças de subsistência, as terras de cultura. Distintos desses posseiros antigos, há os posseiros que, entre os anos 1970 e 1980, vieram de outros municípios e compraram terras da empresa, mas não puderam registrá-las em cartório, pois elas haviam sido penhoradas. Outros ainda trabalharam para a madeireira, e ingressaram no movimento em busca de terras para viver ou de reparações por dívidas. ${ }^{2}$

As Indústrias João José Zattar S/A se estabeleceram em Pinhão no final dos anos 1940, quando lá fundaram uma serraria, ao redor da qual construíram moradias, estabelecimentos comerciais, igreja e escola para seus funcionários. Chamado de Zattarlândia, esse reduto movimentado era um símbolo da prosperidade e do progresso que a empresa prometia trazer à região. Entre aquele período e os anos 1970, a Zattar se expandiu e adquiriu grande quantidade de terras, nas quais viviam posseiros antigos. Para garantir sua propriedade, contratou vigilantes para morar nesses terrenos e impor contratos de arrendamento às famílias que lá viviam. Ao assinar esses papéis, elas se tornavam moradoras do Zattar e assumiam uma série de restrições às suas atividades produtivas. Os vigias, por sua vez, são centrais nas narrativas sobre as ameaças e as mortes propagadas no conflito. Chamados pelos membros dos movimentos sociais de guardas, jagunços e pistoleiros, eles defendiam a propriedade da empresa e cerceavam a autonomia dos posseiros.

Em 1987, os sujeitos expropriados pela Zattar fundaram a Associação das Famílias dos Trabalhadores Rurais de Pinhão (AFATRUP), com a qual iniciaram sua organização política por direitos à terra. Cinco anos depois, criaram o Movimento de Posseiros e reocuparam áreas que haviam sido tomadas pela empresa, que respondeu contratando um novo corpo de guardas para reprimir a organização e suas lideranças. Em 1994, a madeireira decretou falência e fechou seus estabelecimentos industriais em Pinhão. No entanto, permaneceu proprietária das terras, em parte das quais cultivava pinus, e manteve alguns funcionários na antiga Zattarlândia. Em 2006, ofertou cerca de 21 mil hectares ao Incra para desapropriação, negociação que permanece em aberto. Entre 2007 e 2008, uma parte dessas áreas foi ocupada pelo Movimento dos Trabalhadores Rurais Sem Terra (MST), e outra por membros do Movimento de Pequenos Agricultores (MPA) e da Articulação Puxirão dos Povos Faxinalenses (APF).

Após a oferta das terras e a entrada daqueles movimentos sociais, outras famílias de fazendeiros e pequenos proprietários passaram a reivindicá-las, utilizando-se também de força armada. Além deles, alguns grupos 
começaram a explorar ilegalmente as madeiras existentes nessas áreas, gerando novos conflitos e ameaças. Ademais, a Zattar permanece ajuizando ações de reintegração de posse que têm como consequência despejos, o último deles ocorrido em 2017 na comunidade do Alecrim, formada por posseiros que haviam reocupado aquelas terras no início dos anos 1990.

Conforme Figurelli (2012), conflitos por terra escapam a uma definição estável. Seu conteúdo e significados variam segundo as perspectivas dos agentes envolvidos, e misturam-se ao cotidiano, transbordando fronteiras de tempo e espaço. Assim, esta breve síntese não pretendeu substancializar o conflito ou delimitá-lo cronologicamente, mas introduzir essa trama que, ao se estender por terras e através do tempo, produz continuamente novas contestações, relações e mobilizações. As narrativas e as experiências de ameaça e morte que discutirei ao longo do artigo entrelaçam esses tempos, relações, problemas e agrupamentos. O conflito deixa, então, de ser pensado em termos de uma única chave histórica ou oposição, e passa a ser analisado a partir das relações que produz e impõe a famílias e militantes.

A presente discussão parte do pressuposto de que conflitos engendram relações e vida cotidiana e possuem uma dimensão narrativa e performativa, de campo de comunicação público, no qual as categorias acionadas para se falar sobre disputas são também modos de vivê-las e fazê-las (Bauman 1986; Briggs 1996; Marques, Comerford \& Chaves 2007). Ao problematizarem ameaças, agressões físicas e assassinatos, os posseiros acionam uma terminologia particular, que se afasta de termos como "violência" e "crime". Em suas narrativas, as mortes e as ameaças vividas na luta pela terra são muitas vezes tratadas como brigas decorrentes de desaforo ou provocação; brigas de bar; brigas de família; vinganças; esperas e perseguições. Formas de viver e contar sobre acontecimentos disruptivos, estes termos envolvem performances, agenciamentos políticos, produção de autoridade sobre a terra, e permanecem abertos a contestações.

Essas categorias, portanto, não cumprem a simples função de organizar acontecimentos passados. Semelhante ao que ocorre nos "causos" discutidos por Carneiro (2015) e nos "roubos" analisados por Herzfeld (1985), elas exprimem as maneiras com que determinados atos são realizados e com que os sujeitos conhecem o mundo e redefinem suas convenções. Assim, brigas, esperas, vinganças, brigas de família etc. são concebidas como práticas de ameaça, morte e agressão e como termos que, ao serem narrados, explicitam um saber próprio sobre violências vividas na terra e na militância.

De acordo com Feldman (1991), atos de violência agenciam corpos, lugares e objetos, tornando-os parte de uma trama de relações, um lado em um conflito armado. Esses atos são expressos em vocabulários que não se 
limitam a determinados níveis de relações sociais, instituições, contextos, tempos e práticas, mas podem sempre ser aplicados a novas experiências. Termos como briga e espera não decorrem, portanto, de segmentos e modalidades de relação. Afastam-se, nesse sentido, de conceitos utilizados na academia e no âmbito das políticas de promoção de direitos humanos e saúde, como "violência estrutural", "violência política", "violência de gênero", "violência cultural", "violência intrafamiliar", "violência interpessoal". Nas categorias acionadas em Pinhão para se descreverem assassinatos e ameaças, mesmo quando está implícita uma relação, como em briga de família, o que ocorre é que, nos moldes das "intrigas" e "questões" analisadas por Marques (2002), a família não está dada, mas é feita e desfeita através dos conflitos. Além disso, essas categorias são matéria de disputa nas comunidades, cujos membros avaliam os assassinatos e quem participa deles. As pessoas se perguntam, por exemplo, se certas mortes foram brigas de bar ou brigas de família - ainda mais quando ninguém viu quem matou, como acontece nas esperas.

À medida que compõem fatos e narrativas, essas categorias envolvem éticas, ou seja, práticas por meio das quais os sujeitos problematizam a si mesmos e determinadas relações segundo certos parâmetros da vida social (Foucault 2010). A linguagem expressa as avaliações e os compromissos assumidos pelas pessoas, os modos com que incorporam a violência no cotidiano e em suas relações e ponderam as possibilidades de contar sobre si mesmas tendo em vista seu autorrespeito e dignidade (Das 2007, 2015). Em Pinhão, raras vezes os assassinatos nas lutas por terra são chamados de violência e, quando o são, implicam um certo distanciamento desses acontecimentos ou o sentimento de horror, como nos casos que envolvem crianças. Categoria polissêmica e ampla, a briga é a ação e o termo acionado para narrar e refletir sobre ameaças e mortes ocorridas nesses conflitos, incluindo como acontecem ou jamais deveriam acontecer, as qualidades que imprimem em sujeitos e lugares, e seus efeitos na terra, enquanto demanda coletiva que abarca percepções sobre justiça.

"Brigas" e suas éticas são observadas por Fernanda Figurelli (2011) e Renata Lacerda (2019), no caso da primeira autora, para discutir a legitimação de assassinatos de trabalhadores rurais, e da segunda, como situação de enfrentamento envolvendo diferentes agentes e forma de se mobilizar contra o "governo". Thompson (1998) e Scott (1976) encontraram nos valores da vida em comum e das relações entre classes sociais as bases de uma "economia moral", ou seja, os princípios com que camponeses questionam e lidam com a exploração em suas comunidades, e que fundamentam sua organização política. Como afirma Comerford (2014a), a "luta" expressa um "saber 
viver", uma política particular que implica o cultivo de preceitos éticos que permitem enfrentar ou desarmar o perigo e os perigosos, tornando-se assim motivo de orgulho pessoal. Em Pinhão, as brigas também são um modo de problematizar esses valores, e de exprimir os abusos que estão no cerne das lutas pela terra. Ao se expressarem dessa maneira, os posseiros não estão despolitizando sua batalha ou transformando um processo de expropriação em querelas particulares entre eles e jagunços. Ao contrário, é a briga que denuncia as violações de corpos, as relações e os princípios nessa trama de espoliações e a busca por direitos.

O gênero é uma dimensão constitutiva de famílias e terras, de formas de circulação em meio a ameaças, e das próprias brigas. Forma primária de significar relações de poder com base em diferenças concebidas como entre sexos (Scott 1986), e performatividade de normas e significados que regulam as distinções entre masculino e feminino (Butler 1990, 1993), o gênero modula os assassinatos e as ameaças vividos nos conflitos por terra, atribuindo certos lugares, práticas, relações e modos de autoridade a mulheres e homens. É nesse sentido que suscita tensões, dúvidas, possibilidades e limites às brigas. Se as mortes dos homens foram muitas vezes julgadas como desdobramentos de desaforos, brigas de bar e brigas de família, a morte de uma mulher em meio a disputas por terra compreendidas como briga de família foi questionada por outras mulheres como feito que pode ter sido realizado por um marido ruim.

O conflito por terras delineia as condições de minha pesquisa em Pinhão. Fui ao município pela primeira vez em 2009, com a equipe do Projeto Memórias dos Povos do Campo no Paraná, cujo objetivo era documentar e analisar as histórias de grupos que viviam ou haviam vivido conflitos por terra naquele estado. ${ }^{3}$ Assim conhecemos a AFATRUP, que posteriormente nos solicitou a produção de estudos que contribuíssem com o reconhecimento dos faxinais e a criação de assentamentos no município. Ao longo desses anos, tenho sido acolhida por famílias que participam ou participaram do Movimento de Posseiros, do MST e da APF, as quais me recebem em suas casas e me apresentaram seus familiares, comunidades e vizinhanças. ${ }^{4} \mathrm{Em}$ nossas conversas sobre suas experiências na luta pela terra, fui surpreendida com relatos sobre brigas, encrencas, vinganças e jagunços que eram também próximos. O campo me levou aos meandros cotidianos de um conflito que é vivido através de uma linguagem representativa de uma moralidade particular, cujos termos precisei aprender e acionar. São essas vivências das violências propagadas na terra em disputa que busco discutir neste artigo. 


\section{Provocar e desaforar: tecendo brigas}

Os fundadores da AFATRUP mencionam Seu Sebastião como exemplo do sofrimento dos posseiros que tiveram suas terras tomadas pela Zattar. ${ }^{5}$ Ele e sua família são reconhecidos como alguns dos primeiros a entrar na luta contra a madeireira, a qual se iniciou, em seu caso, com a recusa em assinar o contrato. Quando os conheci, Seu Sebastião e sua esposa, Dona Marta, estavam doentes e quase não conversavam. Foram seus filhos Jonas, Marisa e Fernanda, que contaram suas histórias do conflito e de como viveram entre vizinhos tão perigosos.

Seu Sebastião comprou sua posse nos anos 1950. Na década seguinte, a madeireira começou a cortar pinheiros nos faxinais próximos, tempo em que comprou árvores e adquiriu títulos de terras naquela região de Pinhão. Foi então que apareceram sujeitos propondo a assinatura do contrato. A empresa soltou gado por toda aquela área e fez uma casa para os jagunços em frente à de Sebastião, a poucos metros de distância. Com isso, impedia o posseiro de trabalhar e o pressionava a deixar aquelas terras. "Cada semana tinha um jagunço diferente ali" - contou Jonas, que vive com a esposa em uma posse contígua à de seu pai. Disse que eles queriam matar Sebastião e o provocavam para que respondesse às ofensas, dando aos homens de armas um motivo para brigar. A proximidade, assim, era o ingrediente de uma vigilância que intensificava o conflito, incorporando-o ao cotidiano e às relações de comunidade.

Para Jonas, Claudionor foi um dos piores jagunços que viveram na casa da frente. Ele não deixava o posseiro alimentar suas vacas, fazer roça, e matava suas galinhas. Claudionor também costumava amarrar seu cavalo na cruz de cedro da família de Sebastião. A cruz é um símbolo de devoção católica nas comunidades tradicionais de Pinhão, cujos moradores costumavam reunir-se para festejar e rezar quando o cedro brotava. Todas essas atitudes de Claudionor são chamadas também de desaforos, ofensas encaradas como abusos, sinais de máximo desrespeito. Porém, Sebastião jamais responderia ao jagunço como ele esperava. "O pai não sabe nem usar um canivete" - disse Jonas, salientando que seu pai não era afeito a brigas.

Marisa, irmã de Jonas e moradora de outra posse contígua à de seu pai, comentou um acontecimento que me seria narrado também por Fernanda. Sebastião estava trabalhando na roça, com seus filhos por perto, quando os jagunços chegaram. Com as armas apontadas, os homens da madeireira gritaram para ele parar. Assustadas, as crianças correram até o pai e o abraçaram, formando um círculo de proteção. Os jagunços retrocederam. 
Em outra ocasião, Sebastião desabotoou a camisa e, com a mão no peito aberto, disse para os jagunços que, se quisessem matá-lo, poderiam seguir em frente. De novo eles desistiram.

Se Sebastião se manteve vivo por não provocar ou não responder às provocações e aos desaforos, o rapaz Nelsinho, que vivia com sua família ali perto, não teria a mesma sorte. Feita por um jagunço, sua morte revela o potencial destrutivo do desaforo e o papel que desempenhava na produção da autoridade da madeireira sobre a terra. Dirce, irmã de Nelsinho, foi uma das pessoas que me contaram sobre o acontecimento. O jovem foi morto num dia de festa na igreja. Para chegar até lá, ele quis pegar um atalho, o que significava que deveria atravessar um portão do Zattar. Segundo Dirce, o jagunço responsável pela vigilância daquelas áreas não estava em casa quando Nelsinho chegou para pedir permissão para passar. Sua esposa disse ao rapaz que não o deixaria seguir, pois não tinha autorização. Nelsinho desaforou a mulher e passou o portão. Pouco depois de o garoto chegar na festa, o jagunço apareceu, bêbado e bravo, e o matou na frente de todos.

A morte de Nelsinho me foi contada por outros posseiros, os quais salientaram questões diferentes das de Dirce. Diziam que o piá havia sido morto porque passou um portão, motivo que, entre tantos outros, refletia o caráter abusivo da empresa e de seus guardas. Nos interiores de Pinhão, vizinhos e conhecidos não andam somente pelas estradas principais. Para cortar caminho, usam os carreiros, pequenas trilhas em meio ao mato, que atravessam as terras de diferentes moradores. A Zattar impunha, nesse sentido, novas formas e direções a essas mobilidades: enquanto construía cercas e habitava tais áreas com jagunços e, naquela região, gado, a empresa proibia que elas fossem acessadas como caminhos.

Nas palavras de Dirce, porém, o portão emergia como motivo de desaforo: Nelsinho destratou a esposa do jagunço porque ela não quis deixá-lo passar. Se o conteúdo do que foi dito não me foi explicitado, o verbo utilizado (desaforar) é indicativo do inaceitável. Assim, além da liberdade de utilizar um caminho, o que estava em jogo era o comportamento dele com a mulher e o reconhecimento da autoridade do marido dela e do Zattar sobre terras que são também estradas e carreiros.

Os usos que Dirce e os filhos de Sebastião fazem dos termos desaforar e provocar em suas narrativas acentuam o conflito por terras como algo que se produz continuamente através dos gestos e das palavras trocados com jagunços. É por meio dessas dimensões e formas cotidianas que a luta pela terra constitui uma "sociabilidade agonística" (Comerford 2003), dando o tom da vida social e realizando-se em inúmeras situações, como as brincadeiras 
e os jogos, as visitas e as festas e, finalmente, as fatídicas brigas que podem culminar em mortes. Para Comerford (2003:86-7), o ponto nevrálgico de tal sociabilidade é justamente a "provocação", chamado para o enfrentamento perante um público, que pode ser séria ou lúdica, envolve um movimento duplo de interpretação entre "provocador" e "provocado" e a produção de narrativas que conformam reputações.

Xingar, acusar, apelidar, recusar-se a ajudar, desrespeitar símbolos religiosos, fechar caminhos, deixar a criação e os cães ultrapassarem cercas e entrarem em terras alheias, matar a criação dos outros, recusar-se a vender algo para alguém, dedurar podem ser considerados em Pinhão como fazer desaforo, ou mesmo como provocação, que tem como correlato o verbo desafiar. Enquanto a provocação abre caminho para interpretações e sutilezas, podendo ser recebida ou não, respondida ou não, o desaforo demarca a realização de uma ofensa grave. Desaforar ou fazer desaforo é lançar gestos e palavras que, por violarem a integridade de pessoas e as bases do respeito mútuo que se espera dos que vivem em comunidade, serão recebidos como golpes, efetivando brigas e encrencas que são capazes de levar a agressões físicas e assassinatos.

Ao aguentar os desaforos, Sebastião lograva essas brigas e a ameaça de morte. Era isso, afinal, que os jagunços estavam procurando no terreiro dele quando o provocavam. Como afirma Dainese (2015), as experiências de conflito são constitutivas de um repertório de práticas de cuidado de si que reverberam nas relações. Nesse sentido, o comedimento de Sebastião é considerado uma forma de zelar pela família e expressa a sabedoria daquele que é capaz de manter o respeito, nesse caso não por obediência à autoridade do Zattar, mas por si e pelos seus, permanecendo vivo e na terra. O caso de Nelsinho, por outro lado, revela o potencial de morte do desaforo, destacando-se como exemplo do que poderia acontecer aos que não obedeciam ou não se adequavam ao domínio de terras realizado pela madeireira, assegurado também pelos portões e por jagunços que poderiam ser homens ruins. Provocações e desaforos, aqui, impõem autoridade e desmoralizam os posseiros e seus vínculos com terrenos e lugares, transformando seus modos de habitar a terra.

Os casos de Nelsinho e Sebastião indicam ainda que os jagunços não eram sujeitos cuja relação com as terras onde trabalhavam decorria somente do trabalho na madeireira. Como qualquer sujeito que vive no interior de Pinhão, eles eram reconhecidos e avaliados como membros de famílias. Tinham esposas e filhos, com os quais viviam nas casas do Zattar, como aquela em frente à de Sebastião. Parte deles era nascida em Pinhão e participava das tramas de parentesco no município. Seus parentes poderiam 
ou não viver nas mesmas terras que agora eram do Zattar. Assim, as lutas por terras estimulam a consolidação e a dissolução de laços de parentesco, vizinhança e comunidade.

Provocações, desaforos e brigas são formas de refletir sobre as violências vividas considerando-as desde perto, nas maneiras pelas quais ferem a integridade e o respeito entre os sujeitos. O Zattar, modo com que os pinhãoenses se referem à empresa, é tido como uma entidade incorporada por pessoas próximas, como os jagunços, com os quais é preciso, de algum modo, conviver. Essa ética do convívio que tem como base o próprio conflito mostra-nos que as disputas por terras e as violências nelas ensejadas compõem a vida em comunidade enquanto trama de relações e modos de solidariedade e agonística que incluem formas de lidar com a terra, reivindicá-la e torná-la de alguém, ou nossa.

\section{Esperas e perseguições}

Dona Margarida é uma das lideranças posseiras que, entre o final dos anos 1980 e o início dos 1990, acompanhava padres e irmãs vinculados à Comissão Pastoral da Terra (CPT) nas atividades de assistência às famílias ameaçadas pela Zattar. Em nossas conversas sobre suas experiências de luta, ela não falava somente sobre jagunços que moravam perto, mas também dos perigos que encontrava nas estradas. Margarida me contou dos momentos de angústia que viveu com padre Felipe, sabidamente ameaçado de morte. Um deles é descrito por ela no trecho abaixo:

E daí, quando nós estávamos indo com o Felipe, esse meu irmão trabalhava no Fórum, ele sabia tudo né, e ele ficou assim me cuidando. Ele sempre dizia para mim: você não se arrisque muito, você não vá lá, você não faça isso. E daí eu fui com o Felipe levar as coisas para esse povo, e o Faustino tinha visto os guardas do Zattar falarem que iam pegar o Felipe lá na estrada: "Nós vamos matar aquele padre. Vamos matar". E daí o Faustino ficou no Fórum. E cedinho nós fomos com Felipe [...]. Quando nós fomos com o Felipe, esse meu irmão correu lá na secretaria (da Paróquia) e perguntou para a secretária: quem que foi lá para os assentamentos? E ela falou: foi a Dona Margarida e o Felipe. Daí ele disse: mas hoje eles vão matar o Felipe, eles falaram ontem que vão esperar o Felipe! Ele correu na delegacia e pegou dois polícias e foi de atrás de nós, rápido. Quando nós estávamos chegando numa água bonita, uma estrada bonita, para passar no sítio que eles estavam, tinha uma pedra grande no caminho, assim, rolada. Daí o Felipe parou ali e disse: Dona Margarida, olha aí. A tocaia está aí. 
Faustino, irmão de Margarida que trabalhava no Fórum e ouvira os jagunços comentarem seus planos, conseguiu chegar com a polícia a tempo de tirá-los da tocaia. Em razão da pedra rolada, eles permaneceram dentro do carro, e logo em seguida ouviram o ruído da viatura que chegava para escoltá-los até os assentamentos. Margarida contou-me ainda outras histórias de perseguições vividas com Felipe. Numa delas, foram salvos pelo operador de uma retroescavadeira, que atravessou a máquina na estrada, impedindo a passagem dos jagunços que vinham atrás. Outras vezes, tiveram que esconder o carro no mato e ir a pé até as casas de conhecidos que os acobertavam.

As histórias de Margarida nos põem diante da figura da militante como pessoa marcada para morrer, alvo em movimento, aberto a esperas e perseguições. A elaboração dessas arapucas, bem como as artes de saber escapar delas envolvem uma "sistemática do vigiar e do narrar", como Comerford (2014b) nomeia as práticas de observação e controle de movimentos e de conversas que são sempre replicadas em narrativas, tornando-se assim matéria de atenção constante. Essa sistemática consolida um conhecimento indispensável na e para a luta, um saber que constitui aliados e a possibilidade de se escapar do perigo, como ocorreu quando Faustino escutou os jagunços marcarem a espera em que matariam Felipe, que justo naquele dia era acompanhado por Margarida, à qual o irmão estava atento.

Se a provocação e o desaforo são estopins para brigas e encrencas, as esperas podem acontecer no desenrolar delas. Essa forma de ameaçar e matar ocorre em outras brigas e vinganças, para além dos conflitos por terra. Chamadas também de tocaias, elas são armadilhas feitas de pessoas, prontas para abater quem passar. Tais arapucas são arranjadas para cumprir juramentos de morte, cuja execução pode ter sido planejada há um certo tempo, ou para surpreender e matar um desafeto tão logo a briga tenha acontecido. Assim, ainda que tenha esse caráter de surpresa, a espera é anunciada e aguardada, de modo que quase sempre se tem ideia de quem a fez. Os próprios anúncios se tornam tema de observação e de narrativa e são acompanhados como um causo o é ao ser narrado, uma história que se desenrola.

Damião, posseiro que, como Margarida, fundou a AFATRUP, afirma que só escapou das esperas porque o Espírito Santo, do qual sua família é devota, o acudiu. Em uma conversa em que me falava das denúncias e dos processos judiciais, Damião comentou que as testemunhas dos posseiros tinham medo de falar. Perguntei-lhe, então: 
Dibe: E o senhor não tinha medo?

Damião: Do medo sai a coragem (risos).

Dibe: Mas eles assustaram o senhor por causa disso?

Damião: Assustaram. Assustaram não, fizeram até espera, bastante espera para nós, até deu uns avisos. A gente, quando luta pelo certo, a gente tem proteção. Deu uns avisos para a gente, a gente desviou, depois descobriram a espera que eles estavam ali. O nosso padroeiro aqui, o Espírito Santo, não pede licença para Deus pra atender e castigar (risos). E a bandeira dele é vermelha, se a gente estiver com ele, ele está com a gente, é ou não é? [...] No passar na frente onde hoje é a igreja, ali, acabou-se tudo a minha resistência. Mas eu virei um trapo assim! Eu não tinha, não governava as pernas, minhas carnes se esmoreceram tudo, e eu pensei assim: o que será que está acontecendo contra eu? E me deu esses negócios aí, eu não podia mudar o passo mais, me esmoreceu tudo. [...] E eu estava indo junto com o Marcelino, para ele não fez nada, fez para mim. Eu disse para ele: nós negamos essa encruzilhada e entramos por esse carreiro aqui. Passamos dali, voltei de volta, voltou ao normal, tudo de novo. Saímos embaixo da serra e fomos para o Pinhão. Nós íamos até registrar uma queixa do pistoleiro. De volta quando nós viemos de lá, encontramos um dos pistoleiros. Dois cachorrões, ele a cavalo, e disse uma palavra assim: mas que tal vocês! Foram no Pinhão! Foram e voltaram bem, né? - bem desse tipo assim, no encontro de nós. "Que tal vocês, foram no Pinhão e voltaram bem!" Não era só essa espera que tinha, tinha coisa lá no Pinhão para nós.

Observar e controlar movimentos, no caso de Damião, era ativar a relação com um aliado divino, um Espirito Santo que está com a gente, incorporado, e mostrou onde estava o perigo com um aviso no corpo do posseiro que, ao mudar de direção, recuperou suas forças. Muitas das práticas de cuidado de si e dos outros que são mobilizadas nesses conflitos envolvem diretamente a religiosidade dos membros dos movimentos sociais, e isto não só porque a AFATRUP foi formada com o apoio da Igreja Católica em Pinhão, mas porque essas famílias se comunicam cotidianamente com Deus e os santos por meio de orações e dos sinais que eles lhes enviam. ${ }^{6}$

As esperas e perseguições, assim, consistem em ameaças e mortes que são vividas e realizadas na circulação e na fuga de pessoas que esperam e perseguem e de pessoas que são esperadas e perseguidas em trajetos e lugares que se tornam perigosos. Vários membros dos movimentos sociais dizem ainda que são ou foram perseguidos, no sentido de viverem ameaçados e com medo de serem despejados. Nessa conotação, a perseguição inscreve 
um sentimento cotidiano de agonia no sujeito que luta pela terra. As perseguições podem, além disso, ser narradas e discutidas como o movimento de ir de atrás para apanhar alguém de surpresa.

Enquanto as esperas são geralmente feitas em estradas rurais e no mato, as perseguições ocorrem também no Pinhão e às vistas de todos, como aconteceu com Joaquim, que participou das ocupações realizadas pelo Movimento de Posseiros no início dos anos 1990 e por vários anos esteve na direção da AFATRUP. Certa vez, um compadre o avisou que um tal de Chopim, pistoleiro que não conhecia, havia sido empreitado para matá-lo. Numa tarde, quando caminhava pelo centro de Pinhão, Joaquim percebeu que era seguido por um sujeito estranho. Entrou na lotérica para pagar contas e viu que o homem parou na porta, com a mão na cinta e o pé para dentro do estabelecimento. Joaquim pagou contas, jogou na sena, na loto, na quina, e o homem continuava na porta. O posseiro não sabia o que fazer. Quando, enfim, resolveu pedir à moça do caixa para usar o banheiro, viu uma viatura da polícia estacionar do outro lado da rua. Nessa hora, Chopim baixou a guarda e se afastou da porta. Joaquim saiu da lotérica, atravessou a via e entrou em um mercado. Ao sair, não viu mais o homem.

Joaquim: Daquela vez eu não vi mais o Chopim. Depois a gente foi buscar aí, o pessoal correu a ficha dele. Descobriram o nome dele, parece que era Randolfo não sei das quantas. Realmente ele era de Mato Grosso, ele veio naquela época da pistolagem, porque eles tinham interesse de fazer mais despejo, na época não conseguiram só porque a juíza não deixou.

Reconhecer-se como pessoa que está marcada para morrer implica a atenção para quem circula e como circula, bem como o interesse em se saber quem são as pessoas e de onde vêm. Não conhecer Chopim, sujeito de fora, era um problema para Joaquim, que não poderia vigiar seus movimentos, e só durante a perseguição veio a se dar conta de quem era o homem. Além disso, o pistoleiro emerge como um sujeito que tem uma movimentação específica, característica de uma época do conflito, aquela subsequente às primeiras ocupações do Movimento de Posseiros, algumas das quais foram seguidas por despejos.

Pistoleiro é o sujeito pago para matar, que pode oferecer seus serviços a um ou a vários mandantes. Alguns jagunços eram reconhecidos pistoleiros que, além de morar em casas do Zattar e vigiar os moradores, eram empreitados por fazendeiros e empresários da região ou de outros lugares para realizar mortes. Conforme Barreira (1998), pistoleiros agem em conjunto com uma rede que envolve mandantes, intermediários, protetores na polícia e no Poder Judicial; movimentam-se por todo o país, agindo 
como forasteiros anônimos e consolidando carreiras. Em Pinhão, contudo, o pistoleiro é quase sempre alguém conhecido, afamado por sumir por algum tempo e depois retornar com os bolsos cheios de dinheiro. As histórias sobre esses homens versam sobre idas para o Norte, sobretudo para o Mato Grosso, de onde também viera Chopim. O Mato Grosso emerge ainda de histórias sobre famílias ricas que venderam pinheiros e terras para a Zattar, grilaram terras ou se meteram em encrencas e tiveram que fugir, ou partiram espontaneamente para aquele lugar. É como se ele se tornasse, portanto, um sítio de expansão e alimentação das tramas dos conflitos em Pinhão, participando dessa paisagem em movimento das lutas por terra.

As perseguições que Joaquim vivera naquela época da pistolagem contrastam e, ao mesmo tempo, revelam continuidades com as ameaças que vivia em 2011. "Não se assuste se você vir um carro seguindo a gente" - ele me disse numa tarde em que andávamos de carro em Pinhão e tínhamos que passar por um trecho de rodovia. Contou-me que havia denunciado policiais do município envolvidos com o baixo clero da extração de madeira, grupo que retirava o material das áreas que haviam sido ofertadas pela Zattar em 2006. O carro que poderia nos seguir levava homens que Joaquim chamou de $P 2$, policiais militares da divisão de inteligência que o protegiam depois que o crime organizado começou a cercá-lo. Ele já tinha sido perseguido de carro no centro de Pinhão em plena luz do dia por um desses madeireiros clandestinos e o filho de um antigo jagunço. Disse que "foi uma cena de cinema", ele tentando fugir, desviar, jogar o carro na calçada, fazendo cavalo de pau, e os homens atrás dele, numa caminhonete potente.

Depois de descrever a perseguição, Joaquim afirmou que naquele momento seu medo era do crime organizado da madeira, o baixo clero do Zattar, os jaguncinhos que continuavam por lá, escondidos. O baixo clero do Zattar, segundo ele, era formado por sujeitos que, ao mesmo tempo em que prestavam ou já tinham prestado serviços à empresa e poderiam morar e trabalhar nas terras dela, tinham interesses próprios nas madeiras existentes nas áreas ocupadas pelo MST. Além de jaguncinhos e de policiais, o crime organizado da madeira reunia proprietários de terras, empresários e políticos municipais que os posseiros também chamavam de puxas-saco do Zattar, pois apoiaram a empresa em diferentes momentos.

Na narrativa de Joaquim, havia uma conexão entre a pistolagem, os jaguncinhos e o crime organizado. Seus membros poderiam ser os mesmos ou ter relação, e agiam de forma parecida em termos de propagação de mortes, caçando pessoas em esperas e perseguições anunciadas. A polícia, por sua vez, era tratada como um corpo de agentes distintos que, por mais que pudessem oferecer auxílio em certos casos, motivavam desconfianças, 
pois poderiam participar das redes que oprimem os movimentos sociais. O conflito constitui facções que, como o crime da madeira e a pistolagem, são mercados por onde circulam e são trocadas pessoas, terras, árvores, mortes. Como propõe Karina Biondi (2018) em sua análise sobre o PCC, tais facções não correspondem a totalidades ou a uma perspectiva de território predefinido e com limites claros, mas a fluxos e movimentos que unem pessoas em certas atividades e ritmos, compondo lugares e modos de vida. Em Pinhão, as esperas e as perseguições são algumas dessas atividades. Ao se realizarem, elas levam o conflito para além das áreas em disputa, marcando a luta pela terra nos corpos em movimento, e constituindo sujeitos que sabem que, para andarem protegidos diante da morte anunciada, é preciso ouvir e conhecer os passos alheios, e ter aliados, sejam eles humanos ou divinos.

\section{Brigas de bar}

Em suas narrativas sobre as ameaças vividas nos primeiros anos de organização do Movimento de Posseiros, Joaquim e Damião mencionaram o perigo de ir a bares e lá, inadvertidamente, encontrar jagunços e pistoleiros. Foi o que aconteceu com Joaquim, como ele mesmo narrou:

Por isso que não é bom ir em bar, né? Nós estávamos trabalhando na cidade, construindo o colégio. [...] Eu aquele dia fiquei para fazer a janta, fiz a janta, e os companheiros que eram para ter voltado para jantar foram jogar uma sinuquinha lá no bar, do lado do restaurante. Eles não vinham, eu fui chamar eles. Eu dei tanta sorte que quando eu entrei, passei da porta assim da lanchonete onde tinha um joguinho de sinuca, o Paulão encostou bêbado, com mais dois tranqueiras deles. Um era o Alex Soares, esse não desceu do Toyota, ficou lá. E o Tião estava ali, e o Tião é muito labioso, ele é muito sem-vergonha. Antes de ele chegar a gente ainda trocou umas palavras com o Tião, ele chegou a pedir até do meu sogro, perguntar como é que ele estava. [...] Mas no momento que entrou o Paulão, eu tentei ficar de costas, que ele não me reconhecesse. Que desse tempo. Mas foi só ele chegar, daí ele falou assim:

- Conhece esse aqui? Esse aqui é o Carlos Boese, esse o Antonio Boese, lembra do Boese que trabalhou para nós em tal lugar? Aquele lá é o Joaquim, o genro do Seu Pedro.

O homem pediu acho que uma meia. Já estava bêbado né, armado, e o rapaz que estava com ele correu para ficar do lado da porta do lugar. Eu fiquei pálido, disse e agora o que é que eu faço? Daí ele pediu meia dúzia de cervejas e levou 
aquelas garrafas, colocou ali em cima para tomar com os amigos dele, que eu nem conhecia, que era o Carlos Boese e o outro. Porque o pai deles trabalhava para a empresa numa época. A Dona Maria que depois percebeu, já sabia da história, me convidou para entrar. [...] Ela falou: Joaquim, vem cá que eu quero te mostrar uma coisa aqui na cozinha - e desarmou eles também né, impediu. E aí tinha uma saída pelos fundos, ela falou: pegue e saia por aqui e desapareça. Que ele já tinha vindo outras vezes ali naquele espaço e falado na gente, que eles queriam matar eu, o Jorge, o Chico e o Paulo.

Joaquim inicia sua história com uma advertência: não é bom ir em bar. Esses lugares de lazer e interação masculina são também propícios para o encontro com aqueles sujeitos que devem ser evitados. A encrenca, então, pode tornar-se ainda mais grave, já que, numa situação dessas, qualquer palavra trocada arrisca ser recebida como desaforo. Beber e brigar são um par que, justamente por se repetir em inúmeras histórias sobre agressões físicas e mortes que ocorrem e circulam em Pinhão, deve ser considerado quando se atravessa a porta de um desses lugares. Além disso, os bares são o sítio dos valentes, os perigosos bandidos e matadores que, muitas vezes, são também caracterizados como homens que viviam bêbados. Joaquim teve a sorte de encontrar três deles de uma vez, incluindo Paulão e Alex Soares, dois dos mais famosos jagunços e pistoleiros da madeireira, e Tião, o chefe deles. A partir do momento em que estava dentro do estabelecimento, ele conta como foi interceptado pelo próprio Tião, que fez questão de tratá-lo bem (perguntou até sobre seu sogro), e reconhecido por Paulão, que citou Joaquim em voz alta, e estava bêbado e armado.

Como ninguém se salva de uma dessas sozinho, foi Dona Maria, esposa do dono do bar, que já havia escutado os planos dos jagunços, quem deu um jeito de tirar Joaquim de lá. O bar, assim, não é só um lugar onde os encontros perigosos e as brigas podem acontecer. Nele se propagam notícias sobre esses acontecimentos e se declaram anúncios de morte, em conversas que são ouvidas por outros. Tal qual nos casos de esperas e perseguições, a observação da circulação e a conversa de pessoas conforma uma espécie de arte de escapar e de fazer aliados, criando possibilidades de fuga e ausência de certos acontecimentos.

Damião, por sua vez, conta que, em virtude das ameaças que ele e sua família enfrentavam, chegou a pedir permissão ao delegado para andar armado:

Daí eu tinha uma arma naquela época. Fui e falei com o Doutor Costa, promotor: Doutor Costa... - e contei tudo a minha história para ele. Ele disse para mim: o teu revólver é? Eu disse: não é registrado. Ele disse para mim: 
- Você faz o teu registro que eu libero você. Não chegue em bar, não chegue em festa, não beba, não vá em baile, bem escondido, eu te libero para você carregar nessa situação que você está, de perseguido.

Eu disse para ele:

- O cursinho que o senhor está me dando, há muito tempo eu venho fazendo.

E vinha mesmo. Porque bastante companheiro nosso já tinha morrido, a gente tinha experiência.

Este trecho do diálogo é elucidativo tanto do conhecimento das pessoas, dos lugares, de suas conversas e movimentos quanto de um saber sobre os usos de armas e a efetivação de mortes, que Damião sintetiza na expressão ter experiência, consolidada com o acúmulo de situações vividas. Ele afirmava, desse modo, conhecer melhor que o promotor aquelas recomendações de não andar armado em bares, bailes e festas. Afinal, muitos companheiros haviam perdido suas vidas naqueles lugares.

Segundo Carlos, advogado que defende membros dos movimentos sociais, algumas das mortes que ocorreram ao longo do conflito com a Zattar foram tomadas por brigas de bar, não sendo investigadas e nem contabilizadas como parte do conflito. Ele não entrou, contudo, em detalhes sobre esses acontecimentos. Ao longo do meu campo, ouvi diversas histórias sobre o bar que havia na antiga Zattarlândia, onde ocorriam muitas brigas e chegava a ter mais de duas mortes numa única noite, ou onde as brigas começavam e terminavam em esperas na estrada que leva até lá, a qual hoje está cheia de visagens desses mortos. Também conheci a história de um rapaz que foi morto numa espera feita por jagunços que o haviam encontrado no bar, e depois armaram a arapuca para ele em seu retorno para casa. Finalmente, ouvi histórias de jagunços e pistoleiros que perderam a vida em brigas de bar e em festas.

Ao chamar a atenção para os entraves e as ambiguidades que as brigas de bar levavam às denúncias e às investigações de assassinatos que ocorriam no conflito por terras, Carlos nos coloca diante do problema dos limites, enquadramentos e disputas de categorias que entram em jogo na definição de formas de violência enquanto crimes. Para ele, ao tratar certas situações como brigas de bar, as investigações descartavam o conflito por terras, desqualificando tanto a luta dos movimentos sociais quanto os envolvidos na briga, e impossibilitando não só a reparação, mas também o reconhecimento desses conflitos e de suas implicações. 
Confrontos de categorias e reputações são matéria de discussão em diferentes etnografias sobre conflitos e violência no campo. Marques (2002) e Barreira (1998), por exemplo, salientam as manipulações do par "pistolagem" e "vingança" nos julgamentos e nas avaliações públicas sobre certos assassinatos, a primeira referente às mortes pagas e mais condenáveis, e a segunda à morte em retaliação, tida como justificável e até mesmo honrada. Figurelli (2011), por sua vez, discute a "ética da violência" que legitima mortes que são sustentadas como "brigas" decorrentes de ofensas entre trabalhadores rurais e proprietários de terras, ou entre os próprios trabalhadores. A impossibilidade de se delimitar quais "brigas" são do âmbito da ofensa pessoal e quais envolvem a disputa de poder político é também ressaltada por Villela (2004) em seu estudo dos processos-crime no sertão de Pernambuco. Essas distintas etnografias e as reflexões sobre as brigas de bar indicam que estes termos provocam sempre avaliações sobre como certas mortes poderiam ser e são realizadas, julgamentos que não estão pautados na separação entre pessoal e político, público e privado. Embora as brigas de bar possam conformar conflitos particulares, nos casos aqui em questão, elas são modos de fazer e de viver mortes e ameaças no conflito por terras.

Esperas e perseguições podem ser anunciadas e aguardadas, porém, nunca se sabe exatamente onde podem ocorrer. O bar, por sua vez, é o lugar onde as brigas dos homens acontecem e são buscadas. Assim, se para quem está de fora a briga de bar poderia ser tomada como uma espécie de duelo entre sujeitos acostumados a beber e a lançar mão de armas, e compreendida como fato separado das lutas pela terra em Pinhão, os posseiros ressaltam que os bares e as festas são os lugares mais prováveis para a execução de assassinatos, incluindo aqueles que eram propagados nas disputas envolvendo a madeireira, cuja presença se estendia a esses ambientes.

\section{Brigas de família, vinganças e maridos ruins}

Há poucos anos, assim que cheguei em Pinhão para uma rápida estadia, alguns amigos me alertaram sobre brigas de família e vinganças que vinham ocorrendo em uma comunidade próxima às terras de Dona Francisca, senhora posseira que me acolhe em sua casa. Diziam-me que, dessa vez, "até mulher" tinha morrido. Na semana seguinte, quando cheguei na casa de Francisca, ela não tardou a falar de Jocélia Ventura, jovem mãe que ainda amamentava seu bebê quando foi morta. A sequência de assassinatos teve início quando Márcio Ventura foi encontrado à beira da estrada, morto a tiros. Meses depois, mataram Roque Junqueira no meio do mato. Em seguida, Bruno 
Ventura foi alvejado quando chegava no portão de casa. Ele foi socorrido e sobreviveu. Alguns dias depois, sua irmã, Jocélia, foi morta à beira de um olho d'água. Francisca tinha medo do que ainda poderia acontecer. Como ninguém havia presenciado os tiros, ficava difícil tirar conclusões sobre as mortes. Mas parecia que se tratava, sim, de uma briga de família entre os Junqueira e os Ventura.

Os Junqueira queriam tomar as terras ao redor das suas. Apoiados por um fazendeiro, haviam movido uma ação de reintegração de posse contra o MST. Nela reivindicavam a propriedade de boa parte das áreas ocupadas pelo movimento a partir de 2007, após o início das negociações entre a Zattar e o Incra. Afirmavam ainda ser proprietários de terras de herança de outras famílias de sua comunidade, dentre as quais aquelas pertencentes aos pais de um dos genros de Francisca, e os terrenos dos Ventura. A ação foi julgada improcedente. Os Junqueira, porém, não se aquietaram. Passaram a perseguir um antigo guarda da Zattar que havia se aliado aos sem-terra, e a fazer esperas para ele nas estradas. Desconfia-se que eles tenham sido os culpados pelo incêndio da casa de outra família do MST, que resultou na morte de três crianças. Dois anos após essa queima, Márcio Ventura foi morto.

Depois da morte de Jocélia, os Ventura foram passar uns tempos na cidade. Quando voltaram, quase um ano depois, Felipe, irmão da jovem, foi emboscado em uma espera. Ele e outros dois homens foram surpreendidos enquanto seguiam numa caminhonete pela estrada que corta a comunidade. Os dois homens foram mortos dentro do veículo. Felipe correu para o mato, mas foi atingido pelos disparos e caiu no chão. Antes de morrer, conseguiu atirar em Leozil Junqueira, que morreu na hora. Novamente, fui a Pinhão alguns meses depois disso ter acontecido. Francisca e suas filhas falavam agora em briga de família. Mas ressaltavam que aquela havia escapado dos limites, pois mesmo quem não tinha relação com as famílias - como os homens que estavam na caminhonete - virara alvo.

Na última vez em que estive com Francisca, ela contava nos dedos o número de pessoas que tinham perdido a vida naquela briga de família mais de dez até então -, mostrando-me assim a gravidade do conflito, no qual as famílias, como ela disse, estavam "se acabando". "Agora quase só estão sobrando as mulheres" - comentou Francisca. Falou ainda que elas viviam fechadas em casa, com medo de sair e enfrentar esperas. E que elas não tinham nada a ver com a história, e nem Jocélia.

Na qualidade de categoria referente a assassinatos, briga de família geralmente diz respeito a vinganças, que podem ser juradas e perseguidas por famílias em retaliação às mortes de seus membros. A vingança não precisa se concretizar para ter sua eficácia. Narrada e reiterada pelos envolvidos 
e pela comunidade, sua promessa já é capaz de transformar as relações, abrindo novas expectativas de futuro e reorganizando o cotidiano (Gilsenan 1996; Marques 2002; Ayoub 2017). As vinganças podem ser planejadas e realizadas em esperas, perseguições ou encontros em lugares de circulação pública - incluindo estradas, bares e festas. Quando um assassinato acaba de acontecer, a vingança costuma ser tratada como responsabilidade dos familiares mais próximos do morto, como seus pais, irmãos ou familiares que vivem no mesmo terreno, mas nem sempre é assim. As famílias Junqueira e Ventura, desse modo, não devem ser compreendidas como entidades fechadas e determinantes da briga. Ao contrário, é a própria briga que faz e desfaz as famílias que, por sua vez, podem assumir variadas formas e sentidos nessas reivindicações sobre os mortos (Marques 2002; Comerford 2003; Villela 2015; Marques \& Villela 2017).

Este caso é elucidativo das ramificações e transformações contínuas da luta pela terra em Pinhão. O conflito produz disputas e relações que, embora vinculadas às brigas com a madeireira, escapam da oposição entre ela e os movimentos sociais e afirmam-se, no âmbito da vida em comunidade, como brigas de família. Essa forma de briga pode ter múltiplas motivações, mas neste caso é o conflito por terras que a sustenta. A terra é moldada na própria briga e no desenrolar das vinganças, que consolidam a reputação de famílias diante da comunidade e sustentam sua força. Como as vinganças não cessam e pessoas que não têm nada a ver com a história começam a ser mortas, a briga de família parece não ter outro fim possível que não o dos próprios Junqueira e Ventura.

Sendo esse um jogo de destruição dos vínculos entre famílias e terras, os assassinatos de mulheres e crianças afirmam a monstruosidade de seus algozes. Afinal, como aponta Francisca, elas não têm nada a ver com a briga, que parte dos homens e deveria parar neles. No entanto, atentados a mulheres e crianças não deixam de ser recorrentes nos conflitos por terra, nos quais o que se ameaça é a existência da própria família em uma terra que é sobretudo lar, lugar de criação da vida social (Ayoub 2018). Nessa condição, a Jocélia que foi encontrada morta à beira da água era uma Ventura, que incorporava o pertencimento à sua família e às terras onde ela vive.

A morte de uma mulher em meio a um conflito por terras concebido como briga de família levantava outros questionamentos. Dois anos depois do assassinato da jovem, quando comentava comigo os últimos acontecimentos da briga, Dona Francisca disse que Jocélia só estava morando com seus pais "por causa do marido ruim". Ciumento, ele batia na esposa, que se separou dele e voltou para as terras dos Ventura. Teresa, filha de Francisca, contou-me que o assassinato de Jocélia poderia não ter sido obra dos Junqueira e parte 
da briga de família. Mais de uma vez, ela havia visto a moça com o corpo e o rosto marcados por hematomas. Enfatizou que Jocélia foi morta pouco tempo depois de ter se separado do marido, que bebia muito e a agredia. Para Teresa, ele poderia ser o culpado. Porém, como ela mesma frisou, "ninguém viu", então não havia como saber o que de fato ocorreu.

Vividas e narradas como brigas, as mortes e as ameaças que ocorrem nos conflitos por terra têm gênero. O gênero entra em questão como modo de diferenciação, organizando a vida social em termos da divisão masculino/ feminino e implicando formas de habitar a terra, fazer/desfazer família, participar da comunidade e produzir autoridades distintas para homens e mulheres. Assim, se as brigas de bar expressam hábitos de lazer, vícios, formas de agressão e de subjugação referentes aos homens, o caso de Jocélia motivava reflexões sobre outras ameaças vividas pelas mulheres, o que acarretava questionar as assimetrias de poder que perpassam suas casas e seus casamentos. Nessa relacionalidade constituída no conflito, o sujeito que luta pela terra pode, portanto, incorporar perigos que, embora recaiam sobre toda a família, não são necessariamente os mesmos para homens e mulheres.

Como ressaltam diferentes autoras, as relações de gênero põem em xeque a oposição entre doméstico e político, e conectam as formas de violência vividas na vida familiar e nos conflitos armados que envolvem a disputa por terras e territórios (McClintock 1995; Das 2008; Theidon 2004; Vigoya 2018). É essa conexão que o gênero faz entre a família e a terra que está em jogo nas narrativas de Francisca e Teresa. Ao longo do meu trabalho de campo em Pinhão, as agressões sofridas pelas mulheres no âmbito de seus casamentos só eram comentadas quando algo mais grave acontecia - uma separação, um machucado exposto, uma morte. Enquanto alguns desses casos estavam vinculados a maridos bêbados, ciumentos, valentes, que não admitiam a separação, outros envolviam homens que disputavam as heranças de suas esposas.

Esse não dito das outras brigas em família se abria agora nos questionamentos do assassinato de Jocélia. Como ressalta Figurelli (2011:149), as narrativas das mulheres invocam temas muitas vezes velados das lutas pela terra, assuntos que se referem a um mundo público delas, formado por lugares e atividades que escapam ao interesse dos homens ou contrariam a respeitabilidade deles. Contando sobre Jocélia, Francisca e Teresa estendiam outras dimensões das terras em conflito e da própria disputa por terras, que se confundiam com a briga de família e com o marido ruim. Isso impossibilita a definição de um limite entre as agressões referentes à intimidade da vida em família e aquelas vividas nas lutas pelo reconhecimento de assentamentos, como se competissem em diferentes 
esferas de relação. Não era este o movimento analítico feito pelas posseiras. Para elas, o que importava era questionar os múltiplos sofrimentos e as ameaças que se entrecruzavam no corpo de Jocélia, e considerar a briga em suas diferentes possibilidades. Fazendo isso, mostravam que há maneiras e tempos para se falar sobre esses acontecimentos, garantindo a dignidade da morta e a delas próprias, enquanto membros de famílias e comunidades que vivem em luta.

\section{Considerações finais}

Ao ouvir os posseiros de Pinhão narrarem suas histórias de conflito com a Zattar, fui absorvida pelas referências às ameaças e às perseguições vividas na interação com jagunços e pistoleiros. Essas narrativas se misturavam a outros causos de mortes e agressões, e eram contadas através de um vocabulário particular. Formas de fazer e viver assassinatos na luta por direitos, as brigas e demais categorias que compõem essa linguagem expressam também reivindicações de domínio sobre a terra. Considerando isso, tomei estes termos como ponto de partida para uma análise da violência, levando a sério o que diversos autores entendem como uma espécie de problema dessa temática: por um lado, seu caráter moral, de julgamento implicitamente negativo de certas ações, por outro, a ampla diversidade de suas formas (Lenclud et al. 1984; Moore 1994; Medeiros 1996; Misse 2008; Marcelin 2015). Ao dar proeminência às categorias utilizadas pelos posseiros para descreverem os assassinatos e as ameaças de morte vividas na luta pela terra em Pinhão, busquei observar os modos com que eles próprios avaliam moralmente esses acontecimentos e concebem suas diversas manifestações.

Formas de viver e descrever violações, as brigas e demais categorias descritas envolvem os pertencimentos mútuos e as obrigações entre membros de famílias e de comunidades. Processos de expropriação, acumulação e disputas por propriedade são avaliados como afrontas aos preceitos que fundamentam os vínculos entre pessoas e terras. Autonomia, consideração por si e pelos outros, liberdade para trabalhar e para caminhar, comensalidade entre vizinhos, respeito aos espaços comuns, tudo isso dá base à organização política dos posseiros e legitima suas reivindicações. Desaforos, esperas, brigas etc. agenciam pessoas, casas, terrenos, matos, estradas, bares, afetando assim essas éticas e práticas do habitar, trabalhar e se movimentar. Estes termos indicam uma agonística própria ao conflito por terras, que demanda cuidados e se torna matéria da vida cotidiana e de um saber que permite escapar de briga, fazer aliados, reconhecer gestos e sinais, caminhar, observar as pessoas e suas pistas. 
Além disso, estão em jogo as qualidades dos agentes envolvidos nesses processos, como atuam, a quem se aliam e como reclamam sua autoridade sobre determinados terrenos. A madeireira afirmava sua presença nas comunidades através dos jagunços, em um esquema de colonização de terras que permitia a permanência de moradores, mas desorganizava seus modos de ser e de viver enquanto sujeitos autônomos em suas posses. Hoje, a empresa permanece através dos títulos, das ações de reintegração de posse, despejos, negociações com o Incra, das poucas estruturas que mantém na Zattarlândia, seus aliados e funcionários, e das histórias que criou nas áreas que adquiriu. As brigas se renovaram e diversificaram, com a reivindicação das terras por famílias aliadas a fazendeiros, por antigos jagunços e pelo crime da madeira. O conflito e as formas de violência nele propagadas, portanto, variam, efetivando-se de diferentes modos e abarcando distintos sujeitos, tempos e relações.

Há ainda variações que desafiam os enquadramentos das disputas por terras e das mortes que efetivam, as quais se emaranham em brigas de bar e de família, e colidem com homens valentes e maridos ruins. Essas disputas e esses assassinatos não estão fixados em uma tipologia, uma classificação na qual cada termo corresponderia a uma relação particular, e tampouco condizem com regras de conduta. Elas são formas de realizar, reconhecer e refletir sobre ameaças, mortes, agressões e violações. Assim, embora possam acontecer em outros conflitos, ou serem tomadas como conflitos específicos, nos casos aqui discutidos brigas, esperas, desaforos etc. são uma maneira de reivindicar terras e de produzir lados e posicionamentos no conflito com a madeireira e com outros agentes de expropriação.

As brigas estimulam a performatividade criadora do gênero, que diferencia lugares de perigo para homens e mulheres, demarca relações e ambientes e atua nas contestações sobre os assassinatos. Se no caso dos homens o lugar de lazer pode ser aquele onde se é morto, no caso das mulheres a terra-lar emerge como lugar de ameaças vindas dos seus próprios maridos. Na sociabilidade agonística que é forjada através do cotidiano do conflito, esses perigos comporão os modos pelos quais as famílias vivem a luta pela terra e avaliam as mortes.

Em suma, desaforos, provocações, brigas, brigas de bar etc. são formas de propagação e reconhecimento de ofensas graves, que colocam em risco famílias e comunidades. Essas categorias envolvem a realização de gestos, palavras e movimentos, os quais agenciam politicamente lugares, terrenos e pessoas, constituindo-os como participantes das lutas por terra em Pinhão. Vividos como brigas, as mortes e o conflito são problematizados segundo os preceitos éticos que consolidam a vida em comunidade, parâmetros que sustentam também a mobilização política dos posseiros. 
Recebido em 31 de julho de 2020

Aprovado em 12 de fevereiro de 2021

Dibe Ayoub é pós-doutoranda no Programa de Pós-Graduação em Antropologia Social, Museu Nacional, Universidade Federal do Rio de Janeiro (UFRJ), onde também concluiu seu doutorado, e mestra em Antropologia Social pela Universidade Federal do Paraná (UFPR). É membro da coordenação do Núcleo de Antropologia da Política (NuAP) e pesquisadora do grupo de pesquisa Gênero e Ruralidades, sediado na UFRRJ. Desenvolve pesquisas com comunidades tradicionais e movimentos sociais, com foco nos seguintes temas: conflito e violência; terra e política; relações de gênero; relações entre humanos e animais. https://orcid.org/0000-0003-3516-8682

E-mail: dibeayoub@gmail.com

\section{Notas}

1 As expressões com grafia em itálico dizem respeito aos termos elaborados e acionados pelos pinhãoenses nas lutas pela terra. Utilizo aspas duplas para conceitos e citações acadêmicas - sempre acompanhadas de suas respectivas referências - e citações curtas de falas das interlocutoras.

2 A categoria "posseiro" foi forjada nos processos de consolidação da propriedade da terra no Brasil, referindo-se ainda às lutas de camponeses que não possuem os títulos das áreas onde vivem e trabalham. No Paraná, a Revolta de Porecatu (19461951) e a Revolta dos Posseiros do Sudoeste (1957) são casos emblemáticos de conflitos que envolveram posseiros, os quais haviam sido atraídos àquelas áreas por projetos de colonização. Em Porecatu, as disputas se deram com fazendeiros e grileiros que chegaram depois da valorização das áreas (Priori 2011; Silva 2006), e no Sudoeste, com empresas colonizadoras que passaram a exigir que os posseiros assinassem contratos de compra e venda da terra (Gomes 2005; Wachowicz 1985). Em ambos os conflitos, empresas, fazendeiros e grileiros utilizaram a força armada de "jagunços". Referindo-se às demais partes do país, Queiroz (2009) descreve o posseiro como uma modalidade de sitiante que se estabelece em terras não aproveitadas, pertencentes a algum proprietário ausente ou ao governo, e sujeito à expulsão quando ocorre a valorização das áreas e surgem proprietários com títulos verdadeiros ou falsos. Para Martins (1981), o posseiro é um personagem característico da "frente de expansão" 
que avança sobre territórios indígenas; é o camponês livre que perde suas terras para a propriedade capitalista, cujo objetivo é extrair a "renda da terra" através, primeiramente, da compra e venda de imóveis. Ao longo dos anos 1980, diversas etnografias se debruçaram sobre a categoria "posseiro". Enquanto Moura (1988) observou que "posseiros" e "agregados" se confundiam e tinham uma origem comum nas ações judiciais envolvendo a posse da terra no Vale do Jequitinhonha, Musumeci (1988), em trabalho no Maranhão, e Esterci (1987), no Mato Grosso, descreveram o "posseiro" como categoria jurídica incorporada ao discurso dos camponeses sobre seus vínculos com a terra. Esterci compreende o "posseiro" como categoria identitária elaborada na luta de camponeses que resistem à implantação de empresas em suas terras, descrição que os aproxima dos posseiros de Pinhão. Em trabalho recente, Lacerda (2019) relata que a autodefinição como "posseiros" é acionada por sujeitos que detêm ou almejam grandes quantidades de terra no Pará e entram em disputa com famílias de assentados, o que aponta para um novo deslocamento do termo, afastando-o dos "pobres" ou "pequenos".

3 Financiado por um Convênio entre o Instituto de Terras, Cartografia e Geociências do Estado do Paraná e o Ministério da Cultura, o Projeto teve seus resultados publicados em coletânea organizada por Porto, Salles e Marques (2013).

4 Desde 2009, permaneci em Pinhão por cerca de treze meses, com estadias mais longas (quatro meses cada) em 2013 e 2014. Minha última ida ao município foi no verão de 2019. Recebi auxílios financeiros do Projeto Memórias dos Povos do Campo no Paraná e do edital de auxílio à pesquisa do Convênio PPGAS/MN/UFRJ - Capes (2013-2014). Obtive ainda bolsas de pós-graduação e pesquisa da Capes (2009-2011; 2012-2014); Faperj (2014-2016; 2018-atual) e CNPq (2016-2017).

5 Com exceção da empresa madeireira, Zattarlândia, Pinhão e da comunidade do Alecrim, os demais nomes de pessoas e lugares citados neste trabalho são fictícios.

6 A religiosidade é constitutiva das lutas camponesas no Brasil, caracterizando desde os movimentos que participaram da Guerra de Canudos (1895-1898) e da Guerra do Contestado (1912-1916) até a organização de sindicatos nos anos 19601970, quando padres e entidades vinculadas à Igreja Católica adquiriram centralidade na articulação de trabalhadores rurais (Novaes 1997). Considerando essa conexão entre religião e política no campo, Martins (1981:31) afirma que o "misticismo do campesinato" é uma condição social de classe. Seguindo outro caminho de análise, Monteiro (1974) observou a formação de redutos rebeldes durante a Guerra do Contestado como ação ritual, cuja mística incluía a performance de significados e histórias de batalhas características do catolicismo popular. Velho (1995), por sua vez, destaca a "cultura bíblica" elaborada pelos camponeses na Amazônia, os quais acionam uma "simbólica do mal" como parâmetro para a compreensão e a ação diante de situações de privação de liberdade. Essas discussões revelam que as práticas religiosas reiteram moralidades que dão base às maneiras pelas quais os camponeses enfrentam processos de expropriação, seja enquanto movimentos sociais. seja em suas vivências cotidianas na terra. 


\section{Referências bibliográficas}

ALMEIDA, Alfredo Wagner Berno de. 2006. Terras de Quilombo, Terras Indígenas, "Babaçuais Livres", "Castanhais do Povo", Faxinais e Fundos de Pasto": Terras Tradicionalmente Ocupadas. Manaus: PPGSCA-UFAM.

AYOUB, Dibe. 2017. "Fazer vingança, jurar vingança: a morte matada e a vida cotidiana". In: John Comerford, Marcos Otavio Bezerra, Moacir Palmeira, Questões e dimensões da política: anais do Encontro dos 20 anos do Núcleo de Antropologia da Política (NuAP). Rio de Janeiro: Papéis Selvagens. pp. 229-240. . 2018. "Land as Home: Women, Life and Violence in Land Conflicts". Vibrant, 15 (3):1-19.

BARREIRA, César. 1998. Crimes por encomenda: violência e pistolagem no cenário brasileiro. Rio de Janeiro: Relume-Dumará/ Núcleo de Antropologia da Política.

BAUMAN, Richard. 1986. Story, performance and event: contextual studies of oral narrative. Cambridge: Cambridge University Press.

BIONDI, Karina. 2018. Proibido roubar na quebrada: território, hierarquia e lei no PCC. São Paulo: Terceiro Nome.

BRIGGS, Charles L. 1996. "Introduction". In: Charles Briggs (ed.), Disorderly discourse: narrative, conflict and inequality. Oxford: Oxford University Press. pp. 1-40.

BUTLER, Judith. 1990. Gender Trouble: Feminism and the Subversion of Identity. New York: Routledge. . 1993. Bodies That Matter: on the discursive limits of "sex". London: Routledge.
CARNEIRO, Ana. 2015. O povo parente dos Buracos: sistema de prosa e mexida de cozinha. Rio de Janeiro: E-papers.

CHANG, Man Yu. 1988. Sistema Faxinal: Uma forma de organização camponesa em desagregação no Centro-sul do Paraná. Londrina: IAPAR.

COMERFORD, John. 2003. Como uma Família: Sociabilidade, Territórios de Parentesco e Sindicalismo Rural. Rio de Janeiro: Relume-Dumará. . 2014a. "Saber viver, em meio a encrenqueiros, valentões e perigosos". In: César Barreira, Jânia Perla de Aquino, Leonardo Damasceno de Sá, Violência, Ilegalismos e Lugares Morais. Campinas: Pontes Editores. pp. 43-58.

. 2014b. "Vigiar e narrar: sobre formas de observação, narração e julgamento de movimentações". Revista de Antropologia, 57 (2):107142.

DAINESE， Graziele. 2015 . "Desentendimentos entre parentes: variações da intimidade". Revista de Antropologia, 58 (2):371-89.

DAS, Veena. 2007. Life and words: violence and the descent into the ordinary. Berkeley: University of California Press. 2008. "Gender, Violence and Subjectivity". Annual Review of Anthropology, 37:283-299. . 2015. "What does ordinary ethics look like?" In: Michael Lambek, Veena Das, Didier Fassin, Webb Keane (orgs.), Four Lectures on Ethics: Anthropological Perspectives. Chicago: Hau Books/ The University of Chicago Press. 
ESTERCI, Neide. 1987. Conflito no Araguaia: Peões e posseiros contra a grande empresa. Petrópolis: Vozes.

FELDMAN, Allen. 1991. Formations of Violence: The Narrative of the Body and Political Terror in Northern Ireland. Chicago and London: The University of Chicago Press.

FIGURELLI, Mónica Fernanda. 2011. Família, escravidão luta: histórias contadas de uma antiga fazenda. Tese de Doutorado, Museu Nacional, Universidade Federal do Rio de Janeiro.

. 2012. Registros del conflicto: Miradas sobre ocupaciones de tierra en el Nordeste de Brasil. Buenos Aires: Antropofagia.

FOUCAULT, Michel. 2010. História da Sexualidade 2: O Uso dos Prazeres. São Paulo: Graal.

GILSENAN, Michael. 1996. Lords of the Lebanese Marches: Violence and Narrative in an Arab Society. London and New York: I. B. Tauris Publishers.

GOMES, Iria Zanoni. 2005. 1957: A revolta dos posseiros. Curitiba: Criar Edições.

HERZFELD, Michael. 1985. The Poetics of Manhood: Contest and Identity in a Cretan Mountain Village. Princeton: Princeton University Press.

LACERDA, Renata Barbosa. 2019. "Brigar junto contra o governo: Alianças e disputas na implantação de um Plano de Desenvolvimento Sustentável". Revista Brasileira de Ciências Sociais, 34 (100):1-19.

LENCLUD, Gérard; CLAVERIE, Elizabeth \& JAMIN, Jean. 1984. "Une ethnographie de la violence est-elle possible?". Études Rurales, 95-96:9-21.

MARCELIN, Louis Herns. 2015. "Violence, Human Insecurity and the challenge of rebuilding Haiti: A Study of a Shantytown in Port-au-
Prince". Current Anthropology, 56 (2) :230-255

MARQUES, Ana Claudia. 2002. Intrigas e questões: vingança de família e tramas sociais no sertão de Pernambuco. Rio de Janeiro: RelumeDumará.

MARQUES, Ana Claudia ; COMERFORD, John \& CHAVES, Christine. 2007. "Traições, intrigas, fofocas, vinganças: notas para uma abordagem etnográfica do conflito". In: Ana Claudia Marques (org.), Conflitos, política e relações pessoais. Fortaleza: UFC/FUNCAP/CNPqPronex; Campinas: Pontes. pp. 27-55.

MARQUES, Ana Claudia \& VILLELA, Jorge. 2017. "O sangue e a política: sobre a produção de família nas disputas eleitorais no sertão de Pernambuco". Repocs, 14 (27):33-51.

MARTINS, José de Souza. 1981. Os camponeses e a política no Brasil. Petrópolis: Vozes.

MCCLINTOCK, Anne. 1995. Imperial leather: race, gender and sexuality in the colonial contest. New York: Routledge.

MEDEIROS, Leonilde Servolo de. 1996. "Dimensões políticas da violência no campo". Tempo, 1:126-141.

MISSE, Michel. 2008. "Dizer a violência". Revista Katálysis, 11 (2):165-166.

MONTEIRO, Duglas Teixeira. 1974. Os errantes do novo século: estudo sobre o surto milenarista do Contestado. São Paulo: Duas Cidades.

MOORE, Henrietta. 1994. "The problem of explaining violence in the social sciences". In: Penelope Harvey \& Peter Gow, Sex and Violence: Issues in Representation and Experience. London: Routledge. pp. 138-155.

MOURA, Margarida Maria. 1988. Os deserdados da terra: a lógica costumeira e judicial dos processos 
de expulsão e invasão da terra camponesa no sertão de Minas Gerais. Rio de Janeiro: Bertrand Brasil.

MUSUMECI, Leonarda. 1988. O mito da terra liberta. São Paulo: Vértice/ Editora Revista dos Tribunais/ ANPOCS.

NOVAES, Regina. 1997. De Corpo e Alma: Catolicismo, classes sociais e conflitos no campo. Rio de Janeiro: Graphia.

PORTO, Liliana. 2013. "Uma reflexão sobre os faxinais: meio-ambiente, sistema produtivo, identidades políticas, formas tradicionais de ser e de viver". In: Liliana Porto; Jefferson de Oliveira Salles \& Sônia M. dos Santos Marques (orgs), Memórias dos Povos do Campo no Paraná-Centro-Sul. Curitiba: ITCG. pp. 59-77.

PORTO, Liliana; SALLES, Jefferson de Oliveira \& MARQUES, Sônia M. dos Santos. 2013. Memórias dos Povos do Campo no Paraná - Centro-Sul. Curitiba: ITCG.

PRIORI, Angelo. 2011. O levante dos posseiros: a revolta camponesa de Porecatu e a ação do Partido Comunista Brasileiro no campo. Maringá: Eduem.

QUEIROZ, Maria Isaura Pereira de. 2009 [1963]. "Uma categoria rural esquecida". In: Clifford A. Welch et al. (orgs), Camponeses Brasileiros. Leituras e Interpretações clássicas. São Paulo/Brasília: UNESP/NEAD. pp. 57-72.

SCOTT, James C. 1976. The Moral Economy of the Peasant: Rebellion and Subsistence in Southeast Asia. New Haven and London: Yale University Press.
SCOTT, Joan. 1986. "Gender: A Useful Category of Historical Analysis". The American Historical Review, 91 (5):1053-1075.

SILVA, Osvaldo Heller da. 2006. A Foice e a Cruz: comunistas e católicos na história do sindicalismo dos trabalhadores rurais do Paraná. Curitiba: Rosa de Bassi.

THEIDON, Kimberly. 2004. Entre prójimos. El conflicto armado interno y la política de la reconciliación en el Perú. Lima: IEP.

THOMPSON, Edward P. 1998. "A economia moral da multidão inglesa no século XVIII". In: E.P. Thompson, Costumes em comum. São Paulo: Companhia das Letras. pp. 150-202.

VELHO, Otávio. 1995. "O cativeiro da Besta-Fera". In:_-, Besta-fera: recriação do mundo: ensaios críticos de antropologia. Rio de Janeiro: Relume-Dumará. pp. 13-43.

VIGOYA, Mara Viveros. 2018. "As masculinidades no continuum da violência na Nossa América". In: _, As cores da masculinidade: experiências interseccionais e práticas de poder na Nossa América. Rio de Janeiro: Papéis Selvagens. pp. 157-176.

VILLELA, Jorge Mattar. 2004. O povo em armas: violência e política no sertão de Pernambuco. Rio de Janeiro: Relume Dumará.

. 2015. "Os vivos, os mortos e a política no sertão de Pernambuco". Revista de História, 173:329-35.

WACHOWICZ, Ruy Christovam. 1985. Paraná, Sudoeste: ocupação e colonização. Curitiba: Litero-Técnica. 
TERRA E DESAFORO: VIOLÊNCIA NO CAMPO, BRIGAS E ÉTICAS DE LUTA NOS FAXINAIS DO PARANÁ

\section{Resumo}

O presente artigo analisa experiências de assassinato e ameaça de morte vividas por posseiros do município de Pinhão, Paraná, em um conflito por terras que assume múltiplos desdobramentos. Para tanto, observam-se as categorias que os sujeitos acionam para narrar essas experiências: desaforos, provocações, brigas, esperas, brigas de bar, brigas de família. Esses termos não correspondem a tipologias ou códigos normativos, mas expressam formas de viver e reconhecer violações, bem como um saber sobre os perigos constitutivos de famílias, comunidades e da própria luta. Revelam, ainda, os processos de expropriação em seus aspectos performativo e cotidiano, nos quais a morte e sua ameaça compõem reivindicações sobre pessoas e terras e agenciam sujeitos e lugares no conflito. Essas categorias se caracterizam por sua abertura e permanente contestação, representando as maneiras com que os posseiros avaliam moralmente as violências e tensões implicadas no viver em terras em disputa.

Palavras-chave: violência, conflito, terra, narrativa, ética.
LAND AND OUTRAGE: VIOLENCE IN LAND CONFLICTS, FIGHTS AND THE ETHICS OF STRUGGLE IN THE FAXINAIS OF PARANÁ

\section{Abstract}

This article discusses violence in land conflicts through the perspectives of peasants in Pinhão, Paraná, concerning their experiences of deaths and threats in a struggle that unfolds in multiple ways. The analysis focuses on the terms through which the peasants narrate their experiences: outrages, provocations, fights, ambushes, bar fights, family fights. Such categories do not correspond to typologies or normative codes. Instead, they express forms of living and recognizing violations, and a knowledge of the dangers involved in the constitution of families, communities, and struggles. These categories also reveal the performative and everyday aspects of a dispossession process in which death and the threat of death become ways of claiming rights over people and lands, and of agencying persons and places. The categories remain open to contestation, representing how peasants morally evaluate the forms of violence and the tensions that come with living in disputed lands.

Key words: violence, conflict, land, narrative, ethics. 
TIERRA E AGRAVIO: VIOLENCIA

EN EL CAMPO, PELEAS Y ÉTICAS

DE LUCHA EN LOS FAXINAIS DE

PARANÁ

\section{Resumen}

Este artículo analiza las experiencias de asesinato y amenaza de muerte vividas por campesinos en el municipio de Pinhão, Paraná, en un conflicto por la tierra que adquiere múltiples consecuencias. Se prestará especial atención a las formas que los sujetos utilizan para narrar estas vivencias: insultos, burlas, peleas, emboscadas, peleas de bar, peleas de familia. Estos términos no corresponden a tipologías o códigos normativos, sino que expresan formas de vivir y reconocer situaciones de violencia así como saberes sobre los peligros constitutivos de las familias, las comunidades y la propia lucha. Al mismo tiempo revelan una narrativa sobre los procesos de expropiación en sus aspectos performativos y cotidianos, en los que la muerte y la amenaza de muerte configuran reclamos sobre personas y tierras y agencian sujetos y lugares en el conflicto. Estas categorías se caracterizan por su apertura y contienda permanente, representando las formas en que los campesinos evalúan moralmente la violencia y las tensiones que configuran la experiencia de vivir en tierras en disputa.

Palabras clave: violencia, conflictos, tierra, narrativa, ética. 